\title{
ONLINE GRASSROOTS JOURNALISM AND PARTICIPATORY DEMOCRACY IN SOUTH KOREA
}

\author{
Ronda Hauben
}

\begin{abstract}
This article explores how grassroots journalism and online participation embody the ideals of participatory democracy in the South Korean context. Since 2000, online alternative media in Korea have played a pivotal role in many political events including the 2002 candlelight protests against the SOFA, the 2002 presidential election campaign, and the 2005-06 exposure of the stem cell research fraud of Hwang Woo-suk. A Korean news website OhmyNews (www.ohmynews.com), founded in 2000, has played an important role in spearheading a challenge to the domination of public opinion and the public agenda by the conservative mainstream press. Drawing on the idea of the public sphere pioneered by Jürgen Habermas, this paper examines the creation of new online forms of organisation by netizens as part of the new public sphere made possible by the Internet.
\end{abstract}

\section{THE PUBLIC SPHERE AND SOUTH KOREA}

In the spring of 1996 Jürgen Habermas was invited to South Korea for two weeks to lecture and discuss his concept of a public sphere with Korean scholars. He gave several lectures and participated in workshops where the theoretical and practical aspects of his concept of a public sphere were applied to Korean society. The book 'Habermas and the Korean Debate' (Hang Sang-jin 1998) edited by Han Sang-jin is a collection of the papers presented during the Habermas's Korean seminar. The book includes a paper by Professor Park Hyeong-jun of Dong-A University. This paper (Park Hyeong-jun 1998) is prescient in that it provides a general framework to view an important struggle that has been waged in Korean society over the past decade. Park focuses on the potential of the Internet to make possible the development of a 'new form of participatory democracy'. Already by the mid-1990s, Park noted, 'the quantity of political discussion in cyberspace is con- 
siderable' (Park 1998: 439). He describes how '[e]veryday dozens, or even hundreds, of political "pieces" appear in the major commercial BBSs [bulletin board systems]'.

Park believes that political discussion online represents a yearning for 'participatory democracy', and is a reflection of the 'citizens' desire to intervene in a certain political event or to participate in the decision making process' (Park 1998: 440). He anticipates that such democratic processes will develop in two different forms: where existing social movements plan to increase their online activity; and in the creation of new forms of online organization by 'netizens'. He explains the need to pay attention to the possibility of online social movement activity as a form of what he calls 'electronic participatory democracy' (Park 1998: 440-441). He argues that combining the characteristics of the autonomy of civil society and the Internet would lead to embracing a new collective identity on the part of people online. The new identity is 'a flexible and loose identity' which has 'great potentiality with regard to dispersing critical discourses' (Park 1998: 441). Furthermore, the continuing development of the Internet would encourage non-hierarchical or horizontal social structures. Such developments will contribute to 'the possibility for the formation of a new public sphere' (Park 1998: 442).

Park's paper about the potential for such a new sphere, for 'electronic participatory democracy' to gain a foothold in South Korea, provides the impetus for investigating subsequent developments. Fortunately, there is a rich body of theory and practice to refer to about the South Korean struggle for a more democratic society. The focus of this article is on the development of new online forms and processes, and the role of online grassroots journalism, particularly the online newspaper OhmyNews. It takes as a case study the exposure in 200506 of Hwang Woo-suk's fraudulent claims in stem cell research.

\subsection{The global Internet and the netizen experience in Korea}

Just as the citizen is the significant actor in the struggle for participatory democracy, the netizen is the empowered actor in the participatory democratic processes of the Internet. Describing the development of the netizen as a socially oriented identity, Lee Byoung-kwan writes (Lee Byoung-kwan et al. 2005: 58): 
[Michael] Hauben (1997) ${ }^{1}$ defined the term Netizen as the people who actively contribute online towards the development of the Internet ... In particular, Usenet news groups or Internet bulletin boards are considered an 'agora' where the Netizens actively discuss and debate upon various issues ... In this manner, a variety of agenda are formed on the 'agora' and in their activity there, a Netizen can act as 'a citizen who uses the Internet as a way of participating in political society ...'.

Recent developments in South Korea provide a laboratory where netizens have endeavoured to test the potential of the Internet to provide a new form of public sphere, as a means for the citizen to participate in public life and to create an impact upon the decision-making processes of society.

\section{PARTICIPATORY DEMOCRACY IN THE KOREAN CONTEXT}

In response to a question about why his organisation, People's Solidarity for Participatory Democracy (PSPD) included the word 'participatory democracy' in its name, Lee Tae-ho, the organisation's deputy general secretary, referred to the candlelight demonstrations in the former East Germany that had helped to bring down the Berlin Wall in $1989 .^{2}$ Lee said that the spirit of these demonstrations, contained in the slogan of the Germans, 'We are the people', is 'especially important', because it helps to illustrate what is meant by participatory democracy. 'For me personally', he explained, 'there is some continuity between the candlelight demonstrations in Germany and Korea.' With the end of the cold war, Lee elaborated, it becomes clear that there is no way to have democracy without the participation of the citizens.

Lee noted that even with the political reforms of June 1987 in South Korea, and the constitutional processes put in place to replace the military government, the power of the state remained strong and overpowering for the citizens. Without overcoming these obstacles it would not be possible to build democracy. So participatory democracy, he explained, is not just about the participation of citizens, but also involves observation and control over the aspects of state power by the citizens.

\footnotetext{
${ }^{1}$ Hauben, Michael (1997), 'The Net and Netizens: The Impact the Net has on People's Lives', in: Hauben and Hauben: 3-34.

${ }^{2}$ Interview with LeeTae-ho, 18 July 2006.
} 
Some scholars writing about the struggle for democratisation in South Korea explain that it was not until 1997, ten years after the June 1987 reforms, that there was an actual transfer of political power to opposition parties. At the time of this transfer, however, the conservative media remained as one of the arbitrators of the form that any reform of the political system would take. After June 1987, rather than the conservative media being curtailed, it emerged as an 'independent political institution' (Chang 2005a: 928. See also Choi 2005; Kang 2005). Other scholars emphasize the need to reform the conservative media. 'Without the reform of the media, no success of democratic reform is possible', argues Cho Hee-yeon, one of the founders of PSPD (Cho 2001: 4).

The three most powerful conservative newspapers are Chosun Ilbo (5 March 1920), Donga Ilbo (5 April 1920), and JoongAng Ilbo (22 September 1965). These three, each with circulation figures of around 2 million, have a combined market share of 70 per cent (Lee Eun-Jung 2004: 624). According to the Sisa Journal (3 January 2002), no politician has 'won elections against the will of these newspapers' (Lee Eun-Jung 2004: 634).

\section{OHMYNEWS}

OhmyNews began in February 2000 with the explicit objective of bringing about a shift in the balance of power of the media in South Korea. OhmyNews was started by Oh Yeon-ho, formerly a journalist for the Monthly Mal, an alternative magazine owned by the Citizen's Coalition for Democratic Media. Oh worked for Mal as a journalist for the decade following 1988. In July 1994, he published a story with indepth coverage of the 1950 No Gun Ri massacre of South Korean civilians by US soldiers during the Korean War. The mainstream conservative Korean press ignored the story at the time, though there was a reference to the Mal story in the progressive daily newspaper Hankyoreh.

Several years later, in 1999 some Associated Press (AP) reporters wrote about the incident. The mainstream Korean news media from the Korean Broadcasting System to Chosun Ilbo wrote articles based on the AP story, as if it were breaking news, explained Oh. Not only did the South Korean government take it up, but the AP reporters won a Pulitzer for their article. While the AP story included accounts from 
US soldiers who had been involved, an element which had not been part of Oh's story, this experience led Oh to conclude that it was not the nature of the news that governed how much attention a story received, but the power of the news media organisation that determined what was to be considered as news (Oh 2005).

As a reporter for a small alternative publication, Oh experienced discrimination in his effort to cover stories. Nor did journalists for the mainstream conservative media treat him as a fellow journalist. Oh observed that power was maintained by the mainstream media via their ability to set the standards for what was considered news, news gathering and news distribution. With the creation of OhmyNews, Oh was determined to make fundamental changes in the process of news gathering, production and distribution. One basic change that OhmyNews instituted was to welcome netizens to become journalists. Describing his philosophy, Oh writes (Oh 2004a: 2):

Every citizen is a reporter. Journalists aren't some exotic species, they're everyone who seeks to take new developments, put them into writing, and share them with others. This common truth has been trampled on in a culture where being a reporter is seen as something of a privilege to be enjoyed. Privileged reporters who come together to form massive news media wielded power over the whole process of news production, distribution and consumption.

Readers could submit stories which would be considered by OhmyNews editors for publication. Articles which were accepted were fact-checked, edited and then published. Those who contributed articles were called citizen journalists or citizen reporters. The citizen reporters whose articles appeared in OhmyNews would be paid a small fee; the amount depended on whether the article appeared on the front page or elsewhere in OhmyNews. Oh explains that instead of the standard of most mainstream journalists, 'I produce and you read', OhmyNews had substituted, 'We produce, we read, we change the world together' (Oh 2004b). The concept of 'news' was transformed by OhmyNews. Articles could include opinions as long as the facts were accurate.

Oh started OhmyNews with a small staff of four reporters and limited resources. He was helped by online production of the newspaper, with the Internet providing a platform that would make possible readers' comments and discussion on articles and the means to distribute the newspaper. In order to produce this Internet newspaper, given its small staff, Oh adopted a strategy that he called 'selection and concen- 
tration'. The staff would decide on a focus for their coverage and put their resources into providing substantial coverage of these stories. Though at the beginning priority was given to news about politics, society and non-governmental organisations (NGOs), other sections, including international news, business and culture, were added as the newspaper developed (Oh 2005: 29)

In the business plan for the OhmyNews Foundation, several aspects of OhmyNews are explained in greater detail. ${ }^{3}$ The long-term strategy is to produce 'an Internet daily newspaper superior to Digital Chosun'. OhmyNews will bring innovations to 'journalism culture by a revolution in news production, delivery and consumption culture', and will provide a 'pivot for the federation of reporter-like reporters'. News form and content will be transformed with the goal of 'destroy[ing] the standardized form of news report', striving for the 'best investigative reports', and reporting 'vivid sounds of the field: live reports, audio plus video, if possible'. The third aspect, after strategy and transformation of work methods, will be to 'fire arrows toward specific targets: attack corrupted and privileged areas'. The targeted audience is the 'Young N-generation, progressive activists, and reporters', including 'high school students, college students, 386 generation, $\mathrm{NGO}[\mathrm{s}]$, local activists and reporters'. The philosophy proposed is labelled 'open progressive'. This means that 'We are to pursue open progressive perspectives, criticizing unproductive and stubborn progressives and supporting productive and conscientious conservatives.' While the group PSPD worked to build solidarity among civic activists as an NGO, OhmyNews also sought to create an 'NGO'-News Guerrillas Organization-for solidarity among 'news guerrillas'. Oh explains this term as follows (Oh 2004a):

The dictionary definition of guerrilla is 'a member of small non-regular armed forces who disrupt the rear positions of the enemy'. Citizen reporters can be called guerrillas because they are not professional and regulars and they post news from perspectives uniquely their own, not those of the conservative establishment.

The goal in the business plan is to replace the 8:2 ratio between conservative media and progressive media in South Korea with a 5:5 ratio.

${ }^{3}$ Oh, Yeon-ho (2004), 'Business Plan', Daehanminguk Tuksanpoom, OhmyNews, Seoul: Humanist, pp. 327-353, Translation from Korean into English by Lee Jin-sun. 


\section{CANDLELIGHT DEMONSTRATIONS FOR TWO DEAD GIRLS}

A number of articles in OhmyNews contributed to the success of the 2002 presidential campaign. One particular article which appeared in OhmyNews and other online sites provides an interesting example of the power of the netizen.

In June 2002, an armoured military vehicle driven by two US servicemen ran over and killed two Korean middle-school girls. At the time, however, most Koreans were focused on the World Cup celebrations taking place in Korea. By November 2002, the mood had changed, and there was a clear desire among many Koreans that the soldiers concerned should be punished. The Status of Forces Agreement (SOFA) between the US and the Republic of Korea provided that the soldiers be tried by US courts, not under Korean law, and they were found not guilty. A documentary about the trial and its outcome was shown on Korean television. A few hours after watching the documentary, an OhmyNews citizen reporter, using the name AngMA, posted a message on several forums on the Internet including one at OhmyNews, which read:

We are owners of Korea. We are Koreans who deserve to be able to walk in Gwanghwamun 4 . I cried when I watched the TV documentary broadcast of the event, because until now I didn't understand those who struggle so strongly.

It is said that dead men's souls become fireflies. Let's fill downtown with our souls, with the souls of Mi-seon and Hyo-soon. Let's become thousands of fireflies this coming Saturday and Sunday. Let's sacrifice our private comfortable lives. Please light your candle at your home. If somebody asks, please answer, 'I'm going to commemorate my dead sisters'. Holding candles and wearing black, let's have a memorial ceremony for them.

Let's walk in Gwanghwamun holding a lighted candle. Let's commemorate the lives of Mi-seon and Hyo-soon, who were forgotten in the joy of June. Will the police prevent us? Even if they forbid it, I will walk in Gwanghwamun, even if the police attack me.

We are not Americans who revenge [sic] violence with more violence. Even if only one person comes, it's ok. I will be happy to say hello. I will talk about the future of Korea in which Mi-seon and Hyosoon can take a comfortable rest.

\footnotetext{
${ }^{4}$ Gwanghwamun is the area of Seoul where the US embassy is located. It was off limits for demonstrations.
} 
I'll go on, this week, next week, the following week. Let's fill Gwanghwamun with our candle-light. Let's put out the American's violence with our peace. ${ }^{5}$

AngMA posted this at three different online sites on 28 November 2002 at 04:00, five hours after he had seen the TV documentary. The next day he posted it at OhmyNews. Fifteen thousand people appeared at the first candlelight vigil for the two dead girls on 30 November. The rally was due to netizens and the Internet. The movement continued to develop and expand. So too did the online discussion and debate. By 14 December more than 100,000 people gathered in Gwanghwamun.

Song Yong-hoi (Song 2007) chose this incident as the basis for a study of the media dynamics of five news publications, both online and print, progressive and conservative. Included in the study were the conservative Chosun Ilbo and JoongAng and the progressive Hankyoreh. The online newspapers OhmyNews and Pressian were the two online progressive newspapers included. The period of the study was from 13 June 2002, when the two girls died, to 31 December 2002.

Journalism researchers refer to the concept of 'framing' to indicate how a story is presented. Framing refers to 'a central organizing idea or story line that provides meaning to an unfolding strip of events, weaving a connection among them. The frame suggests what the controversy is above, the essence of the issue' (Gamson and Modigliani 1987: 143). In covering a news issue, two considerations are of special importance. The first is how much attention is devoted to the issue by the publication. The second is how the issue is presented in the publication. Song's findings indicate that in June 2002 there was substantially less coverage of the deaths in the conservative press, while the progressive press, both the print publication Hankyoreh, and the online publications, gave the incident more substantial coverage. For example, during the ten-week period immediately following the deaths, OhmyNews published 1,010 articles, and Chosun Ilbo, 96. After the US court verdict exonerating the soldiers, coverage in all the publications increased, with the greatest amount of coverage in OhmyNews. During this period, the period after the verdict until 31 December 2002, OhmyNews published 1,965 articles, Chosun Ilbo, 604 (Song 2007: 80-81).

\footnotetext{
${ }^{5}$ Message translated from Korean into English by Lee Jin-sun.
} 
Song reports that the content of the articles differed in the different publications as well as the amount of coverage. The sources the journalist uses for an article are part of the mechanism of providing a particular frame for the article. The conservative and progressive publications differed on the sources quoted in their articles. The conservative publications drew on official Korean government sources sympathetic to the US government, portraying the protests as anti-Americanism. The progressive publications, both print and online, focused more on the demonstrations and the protest movement, referring to protest movement sources. The study indicated that in reading accounts of the same event it was at times difficult to recognise that the conservative and progressive publications were talking about the same event.

Another concept used in journalism studies is that of 'agendasetting'. This refers to the fact that issues covered by the mainstream press are also issues that become part of the public agenda. When news is ignored by the mainstream press, it is less likely to get public attention. A focus of the demonstrations was the public demand for revisions of SOFA and for this issue to be part of the public agenda.

One question raised by the findings of Song's study is whether the extensive coverage in the progressive press was a contributing factor to the increasing numbers of people participating in the protests. Another question was whether the extensive coverage in the progressive press increased the coverage of the protests in the conservative press. Such questions are a basis for further study and investigation.

\section{ROH MOO-HYUN'S ELECTION CAMPAIGN}

The candlelight demonstrations of 2002 occurred during a period leading up to the presidential election campaign held that year. Developments in the election campaign were another part of the power struggle between the conservative print media and online discussion by netizens on the Internet. During the campaign, criticism in the print media stirred interest in Roh Moo-hyun, a candidate who was considered to be outside of the political mainstream. The narrow focus of the conservative print media was countered by a broad discussion online of the issues of the election. This discussion utilised a variety of online forms, including discussion groups, online polemics, and online journalism. Responses to the print articles were posted and distributed on the Internet. 
On 12 May 2002, PSPD held an online poll to see which of several candidates was most popular. The poll included Rhee In-je, an advisor to the Millennium Democratic party (MDP) and a member of the National Assembly, Lee Hoi-chang, the head of the Grand National party (GNP), and Roh Moo-Hyun, who appeared to be the candidate least likely to be able to win the election. Yet Roh won the PSPD poll.

The presidency election campaign started out, however, with the appearance that it would follow the form and practice of previous campaigns. The GNP candidate seemed destined for victory. In January 2002, he had visited the US and met with high-level officials, including Vice-President Dick Cheney. The GNP at the time held the majority of seats in the National Assembly, 150 out of 272, and had moreover scored a victory over the Millennium Democratic party of the incumbent president, Kim Dae-jung, in the June 2002 local elections, winning eleven of sixteen contests for mayors and governors (Steinberg 2005).

Up until March 2002, Roh was scoring far behind Lee according to polls such as one reported in Chosun Ilbo (5 March 2002), which gave Lee Hoi-chang 38.7 percent of the vote, and Roh 25.2 percent. In online publications, however, there were signs that the election was going to be more of a close race than was apparent in the print press. An online publication, Digital Times, as early as February 2002 showed Roh ahead of Lee (Yun Seongyi 2003: 220). The significant aspect of the election campaign for Roh was the fact that his candidacy was strongly opposed by the conservative print press. For example, during the primary election, the "major newspapers almost everyday carried articles that both implicitly and explicitly criticized candidate Roh Moo-hyun' (Yun Young-min 2003: 148). Surprisingly, the attacks by the print media served to increase the public's interest in Roh and his campaign. As Yun suggests, '[a]s a result more and more voters must have wondered to themselves "Just who is this Roh Moohyun?"'(Yun Young-min 2003: 154). In his study of the activity on the Internet during the 2002 election, Yun documents the 'sharp increase in the number of visits to Roh's website' and judges 'that must have been the reason why "Roh Moo-hyun" became one of the most popular search terms in the news section of portal sites' (Yun Young$\min 2003$ : 154).

Criticism of Roh by the major newspapers had a David and Goliath effect, with Roh being regarded as the brave David able to slay the more powerful Goliath (Yun Young-min 2003: 148). Attacks on Roh 
that appeared in the conservative print media were quick to draw responses and discussion in online newspapers and discussion forums. If there was a reference in the print media to a speech that Roh gave, the whole speech would be posted online with a response to the article that had appeared in the print media (Lee Eun-Jung 2004: 634). Similarly, online discussions were common, and supporters of Roh would send each other articles they found of interest. The online discussion and exchange of views found particular favour among the younger generations who had previously found politics uninteresting. A feedback loop developed between the articles published in the conservative major print publications and the comments and discussion that occurred online (Yun Young-min 2003: 163). To Lee Eun-Jung, the election of 2002 was 'a power struggle between the main print media and the Internet', and 'for the first time in Korean history, the power of the so-called netizen ... made itself felt' (Lee Eun-Jung 2004: 634, $632)$.

\subsection{Role of netizens in the election campaign}

Prior to the election, most experts would have assumed that it was impossible for Roh to win because of the Internet. But after the election, these same experts would agree that the Internet had played a significant role in the victory (Yun Young-min 2003: 163). Though he is cautious about claiming causality without further study, Yun proposes that the 'so-called experts' should exert caution when making their predictions about 'such events in the future' (Yun Young-min 2003: 163).

Summarising Roh's victory, Yun writes (Yun Young-min 2003: 143):

Cyberspace is making it possible for citizens to choose a political position free from the influence of the mainstream press ... Public opinion, which has been almost exclusively minted by a few mass media, can no longer be hidden beneath the control of the press. The ... effect is expected to break the old equation, 'the opinion of the press = public opinion $=$ prevailing opinion'.

Lee Eun-Jung agrees that something important happened: 'In a sense the netizens mobilized themselves into the political realm, exercising their power as citizens ...' (Lee Eun-Jung 2004: 635), and concludes 
that 'with their electoral revolution the netizens had transformed political culture in Korea' (Lee Eun-Jung 2004: 638).

\subsection{Nosamo: a new online institutional political form}

Crucial to the victory of netizens in the 2002 election was the online fan club they created to build support for Roh. Nosamo was started by Lee Jeong Ki (User ID: Old Fox) on 15 April 2000. Nosamo, also transliterated as 'Rohsamo', stands for 'those who love Roh'. The fan club had members both internationally and locally, with online and offline activities organised among the participants. When Nosamo was created, a goal of the organisation was participatory democracy.

Explaining how the participatory process works, Kim Hee-kyung and her co-authors provide an example from Nosamo's experience (Kim Hee-kyung et al. 2004: 4):

Their internal discussion making process was a microcosm of participatory democracy in practice. All members voted on a decision following open deliberations in forums for a given period of time. Opinions were offered in this process in order to effect changes to the decision on which people were to vote.

Such online discussion and decision-making was demonstrated when members of Roh's fan club disagreed with his decision to send Korean troops to Iraq in support of the US invasion. The fan club members held an online discussion and voted on their web site about the war in Iraq. They issued a public statement opposing the decision to send Korean troops to Iraq. Even though they were members of a fan club, they did not feel obliged to support every action of the Roh presidency.

Initially, Nosamo had 40 members. They shared certain political goals, which included challenging the domination of the conservative press over Korean politics. They also opposed regional loyalty as the basis for electoral success in Korean politics. The meeting launching Nosamo was held in an Internet café ('PC Bang' in Korean) in Taejŏn. Over 100 people attended and the meeting was broadcast live by OhmyNews. Instead of following the existing model of a political party organisation, Nosamo was organised at a local level, sponsoring local activities among its netizen population that included trips to the country's highest mountains, holding campfires on local beaches, and bi- 
cycling and walking between two 'regionally antagonistic' cities, Pusan and Kwangju (Kim Yong-ho 2003: 5). Nosamo's activities were mainly organised online but included many offline political and social activities. The fan club began to draw the attention of those who did not know of its online existence when members of Nosamo worked to help Roh Moo-hyun win the newly instituted primary in the MDP.

Trying to win mass support for the party, the MDP instituted its first open primary election to choose its presidential nominee. Rotating open primaries were held in different cities and provinces from January through April 2002. At first Roh was considered an underdog among the MDP candidates. He came in third in the first primary, but then second in the second primary. By the third primary, held in Kwangju, he came in first (Kim Yong-ho 2003: 6) Nosamo's online membership had found the means to gain support for Roh, helped by the open nature of the primary. In April 2002 Roh won the MDP's formal nomination, but had little formal support from the MDP organisation. Nosamo refashioned itself to provide a more formal organisational form for its presidential candidate. It used its online structure to raise funds for Roh and to organise and carry out a vigorous online and offline campaign. At one point, Roh made an agreement with another presidential candidate, Chung Mong-joon, to hold a televised debate, from which the winner would run against the GNP candidate. Though Roh had trailed Chung some of the time in the polls, and trailed the GNP candidate Lee through much of this campaign period, his Nosamo supporters made sure they were available to be polled about who won the debate. Roh emerged from the televised debate with a score of 46.8 percent in favour, to 42.4 percent for Chung.

OhmyNews and the netizens played a critical role in the hours leading up to the election scheduled for 19 December 2002. Oh and other OhmyNews journalists and citizen reporters covered the evening's events continuously throughout the night. As the election approached, Oh realized he had watched netizens supporting the Roh election phenomenon for two years. Oh wondered if it would be possible for netizens to succeed in their campaign for Roh given the opposition of the conservative media. He describes what happened. Around 22.30 the night before the election, Chung withdrew his support for Roh. Chosun Ilbo announced the event, urging voters to follow Chung's lead and withdraw their support from Roh. OhmyNews continually updated its coverage. Oh reports that the discussion boards on Oh- 
myNews were flooded with comments. The article in OhmyNews about Chung's withdrawal of support received 570,000 hits in the ten hours following the announcement. With the hits it received later that day, making a total of 720,000 , it set a record for the most hits on a single article in OhmyNews in one day (Oh Yeon-ho 2003: 116-17, as described in Chang 2005a: 931). Instead of being dissuaded by Chung's action and Chosun Ilbo's efforts to change the course of what would happen in the election, netizens rallied round Roh, discussing what to do about the turn of events, and urging their family, friends and others to vote. This episode led Oh to the conclusion that the importance of the 2002 election was that it was not based on support for Roh personally, but was a manifestation of 'the desire of young netizens for political reform' (Oh 2005: 66).

After the election victory, reporters from Chosun Ilbo and other conservative news media called to congratulate $\mathrm{Oh}$ and other OhmyNews reporters. According to $\mathrm{Oh}$ (Oh 2005: 70):

OhmyNews did our job as the media by giving the Roh Phenomenon its worth as a news story. For example, on a scale of 100 we gave the Roh Phenomenon a 95 in terms of newsworthiness. Korea's conservative dailies, however, gave it only a 30 . Through our own abilities, we did what the media naturally should have done. We rejected their standards and through on-the-spot coverage we were able to decide just how newsworthy the Roh phenomenon was.

On 19 December, Oh wrote that '[t]he power of the media dominated for 80 years by Chosun Ilbo, Joong Ang Ilbo and Dong-A Ilbo has finally changed. The power has gone from the printed newspaper and the professional journalists to the netizens and citizen reporters' (Oh 2005: 69-70).

During the 2002 presidential campaign, citizens found a way to turn the election campaign into a citizens' event. They became actively involved in debating and exploring the issues that were raised. It was not only the candidates or the elites and their newspapers that participated in the debates. On the contrary, articles in the conservative press about the Roh candidacy were subjected to scrutiny, and citizens could respond in both discussion forums and online newspapers. Citizens had reclaimed their role as participants in the election process, rather than being resigned to the status of passive observers. The citizenry also became watchdogs of the process, as well as participants. They were able to contribute to and spread the discussion among other citizens. The 2002 presidential campaign in South Korea was thus an 
important development in the democratisation of Korea. Out of the debate and discussion emerged a broader form of public opinion than had hitherto been available in Korea.

\section{STEM CELL FRAUD AND THE NETIZENS: A CASE STUDY}

Another important struggle developed in South Korea in the autumn of 2005. A research laboratory at Seoul National University (SNU) directed by the veterinary scientist Hwang Woo-suk published what were considered forefront research papers in the field of stem cell research. His papers, published in Science (vol. 303, no. 5664, 12 March 2004, pp. 1669-74, and vol. 308, no. 5729, 17 June 2005, pp. 1777-83, both papers subsequently retracted by Science), documented a technique for cloning stem cells, to produce patient-specific cell lines to use in the treatment of certain diseases, including Parkinson's disease and diabetes, and of injuries such as spinal column injuries. This research was heralded as providing hope for therapeutic treatment. Skillful in public relations, Hwang successfully cultivated journalists and other media contacts. He was treated as a national hero, and received funding and acclaim from the government of Roh Moo-hyun. Private commercial entities like Posco, South Korea's largest steel corporation, and Korean Airlines supported his work (Yoon 2005).

Even before Hwang's second paper appeared in Science, reporters for the US science journal Nature had visited Hwang's laboratory and learned that some of the ova used in his research may have been donated by women who worked as part of his research team. A woman who is in a subordinate position in a research project is considered to be at risk of being under pressure from her employer to make such a donation. Consequently, such donations are contrary to ethical guidelines requiring donations to be voluntary.

Following this investigation, questions about possible ethical violations in Hwang's research were raised in an editorial in the journal (Nature, vol. 429, no. 6987, 6 May 2004, p.1). A television documentary by PD Notebook, an investigative news programme on Munhwa Broadcasting Corporation (MBC), based on information from one of Hwang's former research colleagues, was produced in the fall of 2005 and aired on 22 November 2005. The documentary raised a number of ethical questions about the ova used in Hwang's research. The television programme promised a follow-up documentary that would raise 
further questions about possible fraud in the research. What followed, however, was a flurry of corporate, government and media support for Hwang. This included mainstream media like Chosun Ilbo, and government officials who formed an unofficial group called 'Hwang'gŭm Pakchwi' ('golden bat') to support Hwang. ${ }^{6}$ Supporters of Hwang created an online web site 'We love Hwang' to plan their defence of him. Only messages supporting Hwang could be posted on the site (Hong and Lee 2006).

After their programme on Hwang, the PD Notebook's website was filled with messages of protest. In the process of investigations for a follow-up programme, the producers of PD Notebook had used a hidden microphone to tape an interview with one of Hwang's researchers, who admitted falsifying Hwang's data. The television interviewers, however, were accused of threatening the researcher they were interviewing, and a campaign was organised to induce the advertisers on PD Notebook to withdraw support from the programme. The followup programme was cancelled on 7 December 2005. Progressive media including OhmyNews and Pressian carried stories challenging the attack on PD Notebook. OhmyNews compared the attacks on PD Notebook and others who were raising questions about Hwang's work to activities, similar to those that took place in Nazi Germany. A few civic and labour groups also defended PD Notebook's investigation of the problems in Hwang's work.

At first Hwang denied any problems with his research. But after the first PD Notebook programme, he acknowledged that ova had been donated by two of the researchers in his lab, a procedure that is in violation under the Helsinki Declaration.

Those challenging Hwang's research could expect to become the object of a public attack. Chosun Ilbo took issue with OhmyNews and Pressian editorially for raising concerns about the research. President Roh promised continued support for Hwang, and the scientist's supporters claimed that the beneficial potential of his research, the prom-

\footnotetext{
${ }^{6}$ Ties with Park Ki-young, Science and Technology Advisor for the President, 'yielded a favourable environment for Hwang in the government, as a non-official group consisting of high-ranking government officials was created to support Hwang's research that includes not only Hwang and Park, but also Kim Byung-joon, Chief National Policy Secretary, and Jin Dae-jae, Information and Communications Minister. The group was dubbed "Hwang 'gŭm Pakchwi", a loose acronym formed from each member's family names, which means "golden bat" in Korean' ('Hwang Woo-Suk' in: Wikipedia, online: http://en.wikipedia.org/wiki/Hwang_Woo-Suk) (accessed 25 April 2007).
} 
ise that it could provide a cure for serious medical problems, was being properly treated as of more importance than possible ethical violations. The fact that a prestigious scientific journal such as Science had published Hwang's research papers was offered as proof that the scientific community had verified his research.

On several online sites, however, there was continuing discussion about this research. At scientists' websites such as BRIC (Biological Research Information Centre), ${ }^{7}$ scieng (Association of Korean Scientists and Engineers), ${ }^{8}$ and the Science Gallery of DC Inside, ${ }^{9}$ a photography web site, messages were posted and the questions raised by Hwang's research discussed. Just when it appeared that the attack on PD Notebook was succeeding, a post appeared on BRIC which would have a significant impact on the outcome of the controversy.

On 5 December 2005, a netizen with the log-in 'anonymous' posted a message entitled 'The show must go on' on the BRIC website. 'Anonymous' explained it was possible to access the website of the journal Science and download the pictures that Hwang had submitted in support of his research. 'Anonymous' reported that he had found two sets of duplicate photos in the collection of pictures. $\mathrm{He}$ invited others on BRIC to take a look for themselves. Many netizens responded to the post, verifying the claims. News of the duplicate photos quickly circulated online, and they were copied or linked to many other sites (Hong and Lee 2006). The following morning, another anonymous netizen challenged the claims that the DNA of the stem cells that Hwang claimed to have produced matched the DNA of the donors. The posts documenting the fabrication of Hwang's research results were widely distributed online. One netizen described how during this period, those online knew the news as it was happening online and only several days later would the news appear in the traditional media. ${ }^{10}$

The scientific community was watching the online discussion. Shortly after the post on BRIC on 5 December, Hwang sent an email to Science acknowledging that there were duplications in the photos he had submitted as the evidence for his research, but said this had been the result of a mix-up. He continued to assert that his research claims were valid. In response to these exposures of the problems in

\footnotetext{
${ }^{7}$ http://postech.ac.kr/ (accessed 25 April 2007).

${ }^{8}$ www.scieng.net (accessed 25 April 2007).

${ }^{9} \mathrm{http}: / /$ www.dcinside.com (accessed 25 April 2007).

${ }^{10}$ Discussion with Kim Hee-won, August 2006.
} 
Hwang's articles, a group of young professors at SNU, his university, called for an investigation. A panel was formed, and, after investigating Hwang's work and examining the notes and records that were made available, concluded that there had been no cloning of stem cells, i.e. no patient-specific stem cells had been produced by Hwang's laboratory. The critique presented by netizens had been proven accurate.

This controversy offers insight not only into the actions of the online community of netizens, but also into the constraints the conservative mainstream media works under. Son Byung-kwan's review of the book, The Country of Hwang Woo-Suk (publisher: Bada) by Lee Sung-joo, a journalist who worked for 13 years at Donga Ilbo, describes the role of Lee's chief editor in censoring the exposure of Hwang's fraudulent work (Son 2006a, Son 2006b). The newspaper's policy was to report the story in a way that was "neither ahead nor behind' other mainstream news organisations. Articles that Lee wrote were rejected or not published until the news was stale, and he was reassigned to another beat to prevent him from continuing to follow the story. The chief editor directed the newspaper to intensify the criticism of MBC PD Notebook instead of reporting the revelations of fraudulent scientific claims against Hwang (Son 2006a; Son 2006b).

Lee's experience was corroborated by staff reporter Kim Hee-won of the Hankook Ilbo in a paper he presented in August 2006, in which he documents some of the mechanism that led to the lack of press coverage of the exposure of the fraud until late in the struggle. Kim's paper is based on interviews with six journalists who were working for broadcasting, newspaper or news agencies during or just before the Hwang affair (Kim Hee-won 2006). Kim describes how Hwang had cultivated contacts with mainstream reporters and media organisations. Once the fraud began to be unravelled, reporters who had such contacts recognised that covering the story would jeopardise their relationships with Hwang and his laboratory. When advertisers pulled their ads from PD Notebook in response to public pressure, other news organisations worried about the negative impact articles exposing Hwang might have on their advertisers. One reporter described how his news organisation cultivated both 'pro-Hwang' and 'anti-Hwang' unofficial channels of information. This was reflected in the internal controversy within the organisation and in swings in the nature of its coverage. A reporter from another news organisation explained that his editor did not want any open challenge to Hwang, as 'opinion lea- 
leaders' in business had encouraged the editor to refrain from printing articles that would discredit Hwang. Another reporter referred to internal discussion about what to do once the duplicate photos had been revealed. At first, however, there was no change in coverage. Still another reporter described how his organisation decided to take its time in order to be 'accurate' about its reports and so the media organization did not expose the Hwang fraud.

This series of events demonstrates the developing power of the online media in Korea and how this is presenting a serious challenge to the power of the traditional print media. The online sites of scientific researchers including BRIC, scieng and Science Gallery of DC Inside, were able to stand up against the attacks from the government and media establishment, including online forums set up to defend Hwang. The netizens of BRIC, scieng and DC Inside were supported by others in the online community, by the discussion and linking of articles on other online forums and blogs, and by online media like OhmyNews and Pressian. One blogger explained that the hierarchy within Korean scientific laboratories makes it difficult for young researchers to speak up and to fight abuse. Yet problems could be pinpointed and then treated seriously via anonymous posts and online discussion.

\section{CONCLUSION}

Certain general characteristics emerge which point toward some general concepts in the development of online journalism. The nonhierarchical form of the online experience contrasts sharply with the hierarchical institutional forms that many Koreans face offline. Similarly, the ability to speak up and express one's opinions contrasts with other aspects of Korean life and experience. Discussion and debate online have functioned as catalysts for offline organisation and demonstrations. Describing the rich array of online forms, Chang Wooyoung writes (Chang 2005b, as quoted in Chang 2006: 3) that:

[T] he progressive camp has taken initiatives in the cyberspace by using various types of online media including PC communication communities, closed user groups (CUGs), independent Internet newspapers, political webzines, portal sites for social movements, fan clubs sites of political leaders, and 'anti' sites. 
Yet when one reads analyses of what is happening in terms of democratisation in Korea, the focus is more commonly on the weakness of the political party structures, or the danger of a strong civil society developing without an adequate institutional structure (Choi 2005, Kim Sun-hyuk 2000). There is little attention to the online new democratic processes and the potential they represent for creating new democratic forms (Park 1998).

Several of the online posts presented in this paper provide examples of the ability of netizens to breach the boundary between the concerns of the individual netizen and the social purpose that characterises citizenship. By the messages they have posted netizens have been able to have an impact on social issues they deem important. Their concerns have been reflected from the grassroots upward. Other netizens build on their concerns or distribute their posts to others. Interactive participation and discussion among netizens is critical and provides a basis to begin to construct a modern theory and practice of participatory democracy.

The form created for Nosamo is a form that encouraged participation and provided the basis for citizens to affect developments in their society. Similarly, the processes pioneered by OhmyNews and other online media offer a design expanding the news and views that define public opinion and the public agenda. Netizens participating on BRIC, scieng and the Science Gallery of DC Inside collaborated to examine the claims in a scientific paper, claims which the peer review process of the journal Science had failed to adequately evaluate. Such new online forms and processes need to be documented and analysed, not ignored or blindly admired.

OhmyNews, Nosamo and science related web sites like BRIC are examples of forms created or utilised by netizens. These are examples of changing institutional forms made possible by the Internet. South Korea, a society where there is much broadband access and democratic ferment, is an environment where such new institutional forms can be explored and lessons learned about their nature and the potential for crafting new democratic processes. Such lessons can be helpful elsewhere if the details are known and lessons shared. 


\section{REFERENCES}

Chang, Woo-young (2005a), 'Online Civic Participation, and Political Empowerment: Online Media and Public Opinion Formation in Korea', in: Media, Culture, and Society, 27 (6), pp. 925-35

Chang, Woo-young (2005b), 'The Political Dynamics of Online Journalism: With a Focus on "Political Webzines"”, in: Media and Society, 13 (2), pp. 157-88

Chang, Woo-young (2006), 'The Structural Transformation of Cyber Public Sphere in Korea: From the Prominence of Progressive Camp to Equilibrium between the Progressive and Conservative Camp', unpublished paper

Cho, Hee-yeon (2001), 'The Role of NGO's in the Democratic Transition', in: Asia Solidarity Quarterly, 3 (Winter), pp. 124-44, http://www.peoplepower21.org/ publication/pub_view.php?article_id=4485 (last assessed July 4, July 2007)

Choi, Jang-Jip (2005), Democracy after Democratization: the Korean Experience, Seoul: Humanitas

Gamson, William, and Modigliani, André (1987), 'The Changing Culture of Affirmative Action', in: Research in Political Sociology, 3, pp. 137-77

Han, Jongwoo (2002), 'Internet, Social Capital, and Democracy in the Information Age: Korea's Defeat Movement, the Red Devils, Candle Light Anti-U.S. Demonstration and Presidential Election During 2000-2002', draft paper, September 2002. Online: http://sai.syr.edu/facultypapers/Han\%207-29-03.pdf (accessed 25 April 2007)

Han, Sang-jin (1998), Habermas and the Korean Debate, Seoul: Seoul National University Press

Han, Sang-jin (2004), 'Confucian Tradition and the Young Generation in Korea: The Effect of Post-Traditional Global Testing', paper prepared for the International Symposium Dialogue among Youth in East Asia Project, Yingjie Exchange Center of Peking University, Delivered 14 January 2004

Hauben, Michael and Hauben, Ronda (1997), Netizens: On the History and Impact of Usenet and the Internet, Los Alamitos CA: IEEE Computer Society Press/John Wiley and Sons

Hauben, Ronda (2005), 'The Rise of Netizen Democracy: A Case Study of Netizens' Impact on Democracy in South Korea', unpublished paper. Online: http://www. columbia.edu/ rh120/other/misc/korean-democracy.txt (accessed 19 April 2007)

Hong, Sungook and Lee, June S. (2006), 'Science Communication and the Role of the Media in Hwang Scandal', unpublished paper

Kang, Myung-koo (2005), 'The Struggle for Press Freedom and Emergence of "Unelected" Media Power in South Korea', in: John Erni and S. K. Chua (eds.), Asia Media Studies: Politics of Subjectivities, London: Blackwell Publishing, pp. 7590.

Kim, Hee-won (2006), 'Why Media Support a Scientific Fraud', paper presented at the EASTS Conference, 3-5 August 2006. Online: http://sts.nthu.edu.tw/easts/ agenda.htm (under Kim's name but not this title, accessed 24 April 2007)

Kim, Heekyung Hellen, Jae, Yun Moon and Yang, Shinkyu (2004), 'Broadband Penetration and Participatory Politics: South Korea Case', in: Proceedings of the 37th Annual Hawaii International Conference on System Sciences, Honolulu: IEEE Conference Proceedings, pp. 1-10

Kim, Sun-hyuk (2000), Politics of Democratization in Korea: the Role of Civil Society, Pittsburgh: University of Pittsburgh Press 
Kim, Yong-ho (2003), 'Political Significance of the 2002 Presidential Election: Outcome and Political Prospects for the Roh Administration', in: Korea Journal, Summer, pp. 230-256

Lee, Byoungkwan, Lancendorfer, Karen M., and Lee, Ki Jung (2005), 'AgendaSetting and the Internet: the Intermedia Influence of Internet Bulletin Boards on Newspaper Coverage of the 2000 General Election in South Korea', in: Asian Journal of Communication, 15 (1), pp. 57-71

Lee, Eun-Jung (2004), 'E-democracy@work: The 2002 Presidential Election in Korea', in: Steven Gan, James Gomez and Uwe Johannen (eds.), Asian Cyberactivism: Freedom of Expression and Media Censorship, Singapore: Friedrich Naumann Foundation, pp. 622-42

Oh, Yeon-ho (2004a), 'The Revolt of the 727 News Guerillas: A Revolution in News Production and Consumption', in: OhmyNews 19 February 2004. Online: http://english.ohmynews.com/articleview/article_view.asp?no=153109\&rel_no= 1 (accessed 25 April 2007)

Oh, Yeon-ho (2004b), 'The End of 20th Century Journalism', speech to 2004 conference of the World Association of Newspapers, Istanbul, 31 May 2004, in: OhmyNews 1 June. Online: http://english.ohmynews.com/articleview/article view.asp?article_class $=8 \&$ no $=169396 \&$ rel_no $=1($ accessed 25 April 2005)

Oh, Yeon-ho (2004), Daehanminguk Tuksanpoom, OhmyNews. Seoul. Humanist, pp. 327-353, Translation from Korean into English by Lee Jin-sun

Oh, Yeon-ho (2005), 'OhmyNews: A Unique Product of Korea', English translation of third draft of unpublished paper, 7 January 2005

Park, Hyeong-jun, (1998), 'The Informatization and Computer Mediated Communication in Korea: An Application of Habermas "Public Sphere Theory", in: Han, Sang-jin (ed.), Habermas and the Korean Debate, Seoul: Seoul National University Press, pp. 421-44

Park, Seung-gwan, and Jang, Gyeong-soeb (2001), Media Power and Agenda Dynamics, Seoul: Communications Books

Son, Byung-kwan (2006a), 'How Media Promoted Hwang Myth', in: Ohmynews, 27, March 2006. Online: http://english.ohmynews.com/articleview/article_view.asp? menu $=c 10400 \& n o=281880 \&$ rel $\_n o=1$ (accessed 25 April 2007)

Son, Byung-kwan(2006b), 'Book Reveals More to Hwang Scandal: Author (Part 2)' in OhmyNews International, 27 March 2006, Online: http://english.ohmynews. com/articleview/article_view.asp?no=281883\&rel_no=1 (accessed 25 April 2007)

Song, Yonghoi (2007), 'Internet News Media and Issue Development: A Case Study on the Roles of Independent Online News Services as Agenda-Builders for AntiUS Protests in South Korea', in: New Media and Society, 9 (1), pp. 71-92

Steinberg, David I. (2005), 'The Evolution of Political Party System and the Future of Party Politics in the Republic of Korea', in: Alexandre Mansourov (ed.), ROK Turning Point, Honolulu: Asia-Pacific Center for Security Studies, pp. 118-40

Yoon, Chang-hee (2005), 'Stem cell controversy being felt by sponsors', JoongAng Ilbo, 16 December 2005, http://joongangdaily.joins.com/article/view.asp? aid=2658162 (accessed 4 July 2007)

Yun, Seongyi (2003), 'The Internet and the 2002 Presidential Election in South Korea', in Korea Journal, Summer, pp. 209-29

Yun, Young-min (2003), 'An Analysis of Cyber-Electioneering: Focusing on the 2002 Presidential Election in Korea', in: Korea Journal, Autumn, pp. 141-64 
